\title{
Simultaneous Arsenic and Iron Oxidation for One-Step Scorodite Crystallization Using Mn Oxide
}

\author{
Ryohei Nishi, Santisak Kitjanukit, Taiki Kondo and Naoko Okibe* \\ Department of Earth Resource Engineering, Faculty of Engineering, Kyushu University, Fukuoka 819-0395, Japan
}

\begin{abstract}
The necessity of arsenic (As) removal from metallurgical wastewaters is increasing. Despite its wide recognition as a natural oxidant, the utility of Mn oxide for scorodite production is mostly unknown. In acidic solutions containing both As(III) and Fe ${ }^{2+}$, simultaneous oxidation of the two progressed by $\mathrm{MnO}_{2}$ and the resultant $\mathrm{As}(\mathrm{V})$ and $\mathrm{Fe}^{3+}$ triggered the formation of crystalline $\mathrm{scorodite}\left(\mathrm{FeAsO} \mathrm{O}_{4} \cdot 2 \mathrm{H}_{2} \mathrm{O}\right)$. At $0.5 \%$ or $0.25 \% \mathrm{MnO}_{2}, 98 \%$ or $91 \%$ As was immobilized by day 8 . The resultant scorodite was sufficiently stable according to the TCLP test, compared to the regulatory level in US and Chile $(5 \mathrm{mg} / \mathrm{L}): 0.11 \pm 0.01 \mathrm{mg} / \mathrm{L}$ at $0.5 \% \mathrm{MnO}_{2}, 0.78 \pm 0.05 \mathrm{mg} / \mathrm{L}$ at $0.25 \% \mathrm{MnO}$. For the oxidation of $\mathrm{As}(\mathrm{III})$ and $\mathrm{Fe}^{2+}, 54 \%\left(\right.$ at $0.5 \% \mathrm{MnO}_{2}$ ) or $14 \%$ (at $0.25 \% \mathrm{MnO}_{2}$ ) of initially added $\mathrm{MnO}_{2}$ remained undissolved and the rest dissolved in the post As(III) treatment solution. For the Mn recycling purpose, the combination of $\mathrm{Mn}^{2+}$-oxidizing bacteria and biogenic birnessite (as homogeneous seed crystal) was used to recover up to $99 \%$ of dissolved $\mathrm{Mn}^{2+}$ as biogenic birnessite $\left((\mathrm{Na}, \mathrm{Ca}) 0.5\left(\mathrm{Mn}^{I V}, \mathrm{Mn}^{I I I}\right)_{2} \mathrm{O}_{4} \cdot 1.5 \mathrm{H}_{2} \mathrm{O}\right)$, which can be utilized for the oxidation treatment of more dilute $\mathrm{As}(\mathrm{III})$ solutions at neutral $\mathrm{pH}$. Although further optimization is necessary, the overall finding in this study indicated that Mn oxide could be utilized as a recyclable oxidant source for different As(III) treatment systems.

[doi:10.2320/matertrans.MT-M2021120]
\end{abstract}

(Received June 22, 2021; Accepted September 15, 2021; Published October 22, 2021)

Keywords: arsenite, As(III)-oxidation, scorodite, Mn oxide, Mn recycle, birnessite, Mn-oxidizing bacteria

\section{Introduction}

Arsenic (As)-contaminated wastewaters are a growing problem in metallurgical industries to secure future copper supply from As-bearing minerals such as enargite $\left(\mathrm{Cu}_{3} \mathrm{AsS}_{4}\right)$ and tennantite $\left(\mathrm{Cu}_{12} \mathrm{As}_{4} \mathrm{~S}_{13}\right)$. Generally, the treatment of highly toxic As(III) requires its pre-oxidation to less mobile/ toxic $\mathrm{As}(\mathrm{V})$, followed by the As immobilization step. ${ }^{1,2)}$ Removing soluble As as scorodite mineral $\left(\mathrm{Fe}^{I I I} \mathrm{As}^{V} \mathrm{O}_{4}\right.$. $2 \mathrm{H}_{2} \mathrm{O}$ ) is regarded as an optimal approach for As disposal due to its high stability and density. ${ }^{3)}$ In earlier studies, high concentrations of $\mathrm{As}(\mathrm{V})$ ( $\sim$ hundreds of millimolar) have been chemically mineralized into scorodite by hydrothermal or atmospheric treatments at temperatures mostly 95$160^{\circ} \mathrm{C}^{3-8)}$ After such treatments, some residual As remain to be treated in the form of $\mathrm{As}(\mathrm{V})$, as well as $\mathrm{As}(\mathrm{III})$ that had persisted in the pre-oxidation step. There are also some occasions wherein more dilute As(III) solutions ( $25 \mathrm{mM})$ are produced. ${ }^{8)}$ In order to enable scorodite mineralization at such thermodynamically less feasible, lower As concentrations even under milder conditions, microbiological approaches have also been proposed. ${ }^{8-14)}$

Manganese (Mn) is the 10th most abundant element in the Earth's crust and 2nd (only to iron) most common heavy metal. ${ }^{15)}$ Over $30 \mathrm{Mn}$ oxyhydroxide minerals are known in diverse geological settings, which are thought to participate in various chemical reactions to affect groundwater and soil compositions. ${ }^{15)}$ In nature, such Mn oxides can behave as chemical oxidants, consequently playing a critical role in the geochemistry of various heavy metals (e.g., $\mathrm{Cr}(\mathrm{III}),{ }^{16}$ ) $\left.\mathrm{Co}^{2+},{ }^{17)} \mathrm{As}(\mathrm{III}),{ }^{18-21)} \mathrm{Fe}^{2+22)}\right)$. The more electro-positive standard redox potential of the $\mathrm{Mn}(\mathrm{IV}) / \mathrm{Mn}^{2+}$ couple $(+1.3 \mathrm{~V})$ than that of $\mathrm{As}(\mathrm{V}) / \mathrm{As}(\mathrm{III})(+0.56 \mathrm{~V})$ enables the oxidation of $\mathrm{As}$ (III) by $\mathrm{MnO}_{2}$, as described by eq. (1):

*Corresponding author, E-mail: okibe@mine.kyushu-u.ac.jp

$$
\begin{aligned}
& \mathrm{H}_{3} \mathrm{As}^{I I I} \mathrm{O}_{3}+\mathrm{Mn}^{I V} \mathrm{O}_{2}+\mathrm{H}^{+} \\
& \quad \rightarrow \mathrm{H}_{2} \mathrm{As}^{V} \mathrm{O}_{4}{ }^{-}+\mathrm{Mn}^{2+}+\mathrm{H}_{2} \mathrm{O}
\end{aligned}
$$

This reaction involves the formation of $\mathrm{Mn}$ (III) intermediate $\left(\mathrm{Mn}^{I I I} \mathrm{OOH}^{*}\right)$ (eq. (2)), which can be later reduced to $\mathrm{Mn}^{2+}$ by further reacting with $\mathrm{As}(\mathrm{III})$ (eq. (3)): ${ }^{23)}$

$$
\begin{aligned}
& \mathrm{H}_{3} \mathrm{As}^{I I I} \mathrm{O}_{3}+2 \mathrm{Mn}^{I V} \mathrm{O}_{2}+\mathrm{H}_{2} \mathrm{O} \\
& \rightarrow \mathrm{H}_{2} \mathrm{As}^{V} \mathrm{O}_{4}^{-}+2 \mathrm{Mn}^{I I I} \mathrm{OOH}^{*}+\mathrm{H}^{+} \\
& \mathrm{H}_{3} \mathrm{As}^{I I I} \mathrm{O}_{3}+2 \mathrm{Mn}^{I I I} \mathrm{OOH}^{*}+3 \mathrm{H}^{+} \\
& \rightarrow \mathrm{H}_{2} \mathrm{As}^{V} \mathrm{O}_{4}^{-}+2 \mathrm{Mn}^{2+}+3 \mathrm{H}_{2} \mathrm{O}
\end{aligned}
$$

The standard redox potential of the $\mathrm{Mn}(\mathrm{IV}) / \mathrm{Mn}^{2+}$ is also more electro-positive than that of $\mathrm{Fe}^{3+} / \mathrm{Fe}^{2+}(+0.77 \mathrm{~V}$; $\mathrm{pH} 2.0$ ), thus Mn oxides are capable of oxidizing $\mathrm{Fe}^{2+}$ to $\mathrm{Fe}^{3+}$ as described by eq. (4):19)

$$
2 \mathrm{Fe}^{2+}+\mathrm{Mn}^{I V} \mathrm{O}_{2}+4 \mathrm{H}^{+} \rightarrow 2 \mathrm{Fe}^{3+}+\mathrm{Mn}^{2+}+2 \mathrm{H}_{2} \mathrm{O}
$$

The oxidation behavior of Mn oxides was also studied under the coexistence of $\mathrm{As}(\mathrm{III})$ and $\mathrm{Fe}^{2+} .^{24-27)} \mathrm{Han}$ et al. ${ }^{24)}$ reported that the presence of $\mathrm{Fe}^{2+}$ significantly inhibits the removal (oxidation and sorption) of $\mathrm{As}(\mathrm{III})$ by $\mathrm{MnO}_{2}$ in acidic conditions at $25^{\circ} \mathrm{C}$. This was attributed to the formation of $\mathrm{Fe}(\mathrm{III})$ compounds passivating the $\mathrm{MnO}_{2}$ surface. The authors speculated the formation of poorly crystalline particles of FeOHAs and $\mathrm{FeAsO}_{4}{ }^{24)}$ Likewise, Ehlert et al. ${ }^{25}$ ) reported that the oxidation of $\mathrm{Fe}^{2+}$ by birnessite proceeds significantly faster than that of As(III) and the resultant $\mathrm{Fe}^{3+}$ precipitates as As-sequestering ferrihydrite at circumneutral $\mathrm{pH}$ and $25^{\circ} \mathrm{C} .^{25}$ ) The As(III) oxidation kinetics by a poorly crystalline hexagonal birnessite at different $\mathrm{Fe}^{2+}$ concentrations was studied by Wu et al. ${ }^{26,27)}$ at $\mathrm{pH}$ 6. The authors reported the competitive oxidation of $\mathrm{Fe}^{2+}$ over $\mathrm{As}$ (III) and suggested that the resultant precipitation of $\mathrm{Fe}$ (III)-(hydr)oxides on the birnessite surface plays an important role in As(III) oxidation and As sequestration.

Nonetheless, no study so far reported the production of crystalline scorodite by utilizing the oxidation ability of $\mathrm{Mn}$ 
oxides. According to eq. (1)-(4), $\mathrm{Mn}^{2+}$ is reductively dissolved from Mn oxide upon oxidation of As(III) and $\mathrm{Fe}^{2+}$. The metal value of dissolved $\mathrm{Mn}^{2+}$ should be ideally recovered from the post As(III) treatment reaction. Regenerating $\mathrm{Mn}$ oxide from $\mathrm{Mn}^{2+}$ in the post $\mathrm{As}$ (III) treatment solution would enable Mn recycling in this regard. One of the most economically feasible approaches for $\mathrm{Mn}$ oxide regeneration would be the use of Mn-oxidizing microorganisms since microbial Mn oxidation proceeds at neutral $\mathrm{pH}$ (instead of alkali $\mathrm{pH}$ in chemical reactions). For this aim, the objectives of this study were set to evaluate; (i) the utility of Mn oxide for the oxidative removal of As(III) as scorodite, and (ii) the feasibility of Mn recovery from the post As(III) treatment solution using the Mn-oxidizing bacterium.

\section{Materials and Methods}

\subsection{Effect of $\mathrm{MnO}_{2}$ on individual oxidation of $\mathrm{As}(\mathrm{III})$ and $\mathrm{Fe}^{2+}$}

Different doses of $\mathrm{MnO}_{2}$ (138-09675, Wako chemicals; $0.15,0.25$ or $0.5 \%(\mathrm{w} / \mathrm{v}))$ was added into $100 \mathrm{~mL}$ deionized water $\left(\mathrm{pH}_{\text {initial }} 1.5\right.$ with $\left.\mathrm{H}_{2} \mathrm{SO}_{4}\right)$ containing either $1000 \mathrm{mg} / \mathrm{L}$ $(13 \mathrm{mM})$ of $\mathrm{As}(\mathrm{III})$ (added as $\mathrm{NaAsO}_{2}$ ) or $1000 \mathrm{mg} / \mathrm{L}$ $(18 \mathrm{mM})$ of $\mathrm{Fe}^{2+}$ (added as $\mathrm{FeSO}_{4} \cdot 7 \mathrm{H}_{2} \mathrm{O}$ ) in $300 \mathrm{~mL}$ Erlenmeyer flasks. The flasks were incubated shaken at $100 \mathrm{rpm}, 70^{\circ} \mathrm{C}$. Samples were regularly withdrawn to monitor $\mathrm{pH}$, Eh (vs. SHE) and concentrations of $\mathrm{Fe}^{2+}(o-$ phenanthroline method ${ }^{28)}$ ), As(III) (molybdenum blue method $^{29,30)}$ ) and total soluble Fe, As and Mn (ICP-OES; Optima8300, PerkinElmer). All tests were done in duplicate flasks.

\subsection{Effect of $\mathrm{MnO}_{2}$ on simultaneous oxidation of $\mathrm{As}(\mathrm{III})$ and $\mathrm{Fe}^{2+}$ for scorodite precipitation}

Different doses of $\mathrm{MnO}_{2}(0.15,0.25$ or $0.5 \%$ (w/v)) were added into $200 \mathrm{~mL}$ deionized water $\left(\mathrm{pH}_{\text {initial }} 1.5\right.$ with $\left.\mathrm{H}_{2} \mathrm{SO}_{4}\right)$ containing both $1000 \mathrm{mg} / \mathrm{L} \mathrm{As}(\mathrm{III})$ and $1000 \mathrm{mg} / \mathrm{L} \mathrm{Fe}^{2+}$ (to set the $\mathrm{Fe} / \mathrm{As}$ molar ratio at 1.3 ) in $500 \mathrm{~mL}$ Erlenmeyer flasks. The flasks were incubated shaken at $100 \mathrm{rpm}, 70^{\circ} \mathrm{C}$. Sampling and analytical methods were described in section 2.1. All tests were done in duplicate flasks.

\subsection{Toxicity characteristic leaching procedure (TCLP) test}

In order to examine the stability of scorodite crystals formed in section 2.2., the TCLP test was performed according to the EPA method 1311 (US EPA method 1311). An aliquot of scorodite sample $(0.15 \mathrm{~g})$ was added into $5 \mathrm{~mL}$ serum bottles containing $3 \mathrm{~mL}$ acetate buffer ( $\mathrm{pH}$ 4.9). Serum bottles were rotated at $30 \mathrm{rpm}, 25^{\circ} \mathrm{C}$, for 18 hours using a rotary shaker. The leachate was filtered $(0.6 \mu \mathrm{m})$ and measured for the total soluble $\mathrm{Fe}$ and As concentrations (ICP-OES). The test was conducted in duplicate bottles.

\subsection{Mn recycling via microbiological Mn oxide (birnes- site) regeneration}

\subsubsection{Microorganism}

Mn-oxidizing bacterium, Pseudomonas sp. SK3 (isolated from a metal-refinery wastewater treatment system ${ }^{25)}$ ) was used. Its routine sub-culturing used half-strength lysogeny broth (LB) medium $(0.5 \%(\mathrm{w} / \mathrm{v}) \mathrm{NaCl} ; 0.5 \%(\mathrm{w} / \mathrm{v})$ tryptone; $0.25 \%(\mathrm{w} / \mathrm{v})$ yeast extract) in Erlenmeyer flasks (shaken at $120 \mathrm{rpm}, 25^{\circ} \mathrm{C}$ ). Cells were pre-grown overnight, collected and washed with $0.8 \%(\mathrm{w} / \mathrm{v}) \mathrm{NaCl}$ solution prior to use in the following Mn oxidation tests.

\subsubsection{Regeneration of Mn-oxide from the post As(III)- treatment solution}

The post As(III)-treatment solution after scorodite precipitation (section 2.2) was subjected to the following Mn recycling step by utilizing the microbial Mn-oxidizing activity. Pre-grown Pseudomonas sp. SK3 cells $\left(10^{9}\right.$ cells $/ \mathrm{mL}$ ) were inoculated into $100 \mathrm{ml}$ of the post $\mathrm{As}(\mathrm{III})$ treatment solution (diluted by 16-fold) supplemented with inorganic salts $\left(2 \mathrm{mM} \mathrm{MgSO} 4 \cdot 7 \mathrm{H}_{2} \mathrm{O} ; 0.07 \mathrm{mM} \mathrm{CaCl} 2 \cdot 2 \mathrm{H}_{2} \mathrm{O}\right.$; $3 \mu \mathrm{M} \mathrm{CuCl} 2)$ and organic substrates $(0.01 \%(\mathrm{w} / \mathrm{v})$ yeast extract; $0.01 \%(\mathrm{w} / \mathrm{v})$ peptone; $1 \mathrm{mM}$ glucose). The initial $\mathrm{pH}$ was adjusted to 5.0 or 7.0 with $\mathrm{NaOH}$. The effect of seed crystals was also compared by feeding $0.1 \%(\mathrm{w} / \mathrm{v})$ biogenic birnessite. Biogenic birnessite was separately produced by Pseudomonas sp. SK3, collected, freeze-dried prior to use (the freeze-drying process deactivated bacterial cells). Flasks were incubated shaken at $120 \mathrm{rpm}$ at $25^{\circ} \mathrm{C}$. Samples were regularly taken to monitor $\mathrm{pH}$ and the total soluble $\mathrm{Mn}$ concentration (ICP-OES). All tests were done in duplicate flasks.

\subsection{X-ray diffraction (XRD) and scanning electron microscope (SEM) analyses}

Mn precipitates formed in section 2.4 .2 were collected by filtration $(0.45 \mu \mathrm{m})$, washed with deionized water and freezedried overnight prior to the XRD (UltimaIV, Rigaku; $\mathrm{CuK} \alpha$ $40 \mathrm{~mA}, 40 \mathrm{kV}$ ) analysis and SEM (VE-9800, KEYENCE) observation.

\section{Results and Discussion}

\subsection{Individual oxidation of $\mathrm{As}(\mathrm{III})$ and $\mathrm{Fe}^{2+}$ by $\mathrm{MnO}_{2}$}

As(III) oxidation at different $\mathrm{MnO}_{2}$ doses is shown in Fig. 1. $\mathrm{pH}$ remained unchanged throughout the experiment (data not shown). Since the total soluble As concentration was nearly unchanged throughout the test (data not shown), both $\mathrm{As}(\mathrm{III})$ and $\mathrm{As}(\mathrm{V})$ ions remained mostly soluble without noticeable adsorption or precipitation on the $\mathrm{MnO}_{2}$ surface. $\mathrm{As}(\mathrm{III})$ was readily oxidized to $\mathrm{As}(\mathrm{V})$ by $\mathrm{MnO}_{2}$ with an increasing reaction speed at higher $\mathrm{MnO}_{2}$ doses (Fig. 1(a)). Accordingly, $\mathrm{Mn}^{2+}$ was released via reductive dissolution of $\mathrm{MnO}_{2}$ (Fig. 1(a)). At $0.25 \%$ and $0.5 \% \mathrm{MnO}_{2}$, the reaction proceeded with a molar ratio of $\Delta[\mathrm{As}(\mathrm{III})$ oxidized $] / \Delta[\mathrm{Mn}$ dissolved] at around 1 (Fig. 1(b)), according to eq. (1). At a lower $\mathrm{MnO}_{2}$ dose of $0.15 \%$, however, the molar ratio decreased towards the later stage (Fig. 1(b)), possibly caused by the increasing passivation effect of the $\mathrm{MnO}_{2}$ surface with Mn(III) intermediate. ${ }^{23)}$

Likewise, the $\mathrm{Fe}^{2+}$ oxidation trend by different doses of $\mathrm{MnO}_{2}$ is shown in Fig. 2. The total soluble Fe concentration remained unchanged throughout the test (data not shown). Therefore, $\mathrm{Fe}^{2+}$ oxidized to $\mathrm{Fe}^{3+}$ by $\mathrm{MnO}_{2}$ existed in the form of a soluble ion. The $\mathrm{Fe}^{2+}$ oxidation reaction was seen as a distinctive two-phase process, where the reaction 

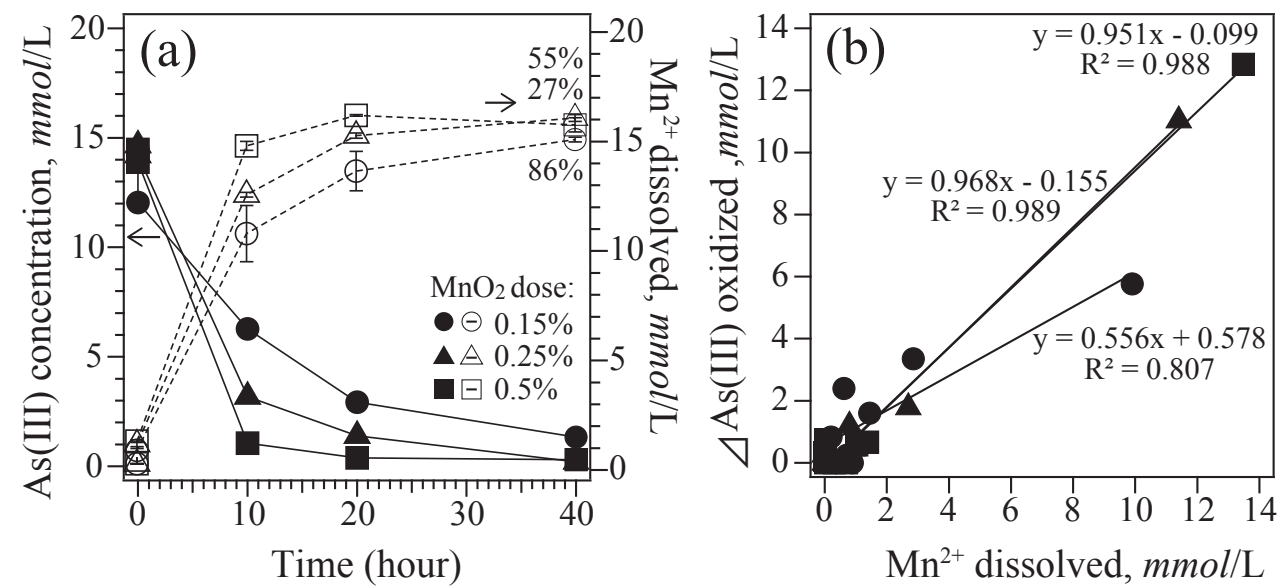

Fig. 1 The effect of $\mathrm{MnO}_{2}$ as an oxidant for $\mathrm{As}(\mathrm{III})$ in acidic solutions $\left(\mathrm{pH}_{\text {initial }} 1.5\right)$. Different $\mathrm{MnO}_{2}$ doses $(\mathbf{\bigcirc} 0.15 \% ; \mathbf{\Delta} \triangle 0.25 \%$; $\square 0.5 \%$ ) were compared: (a) The oxidation trend of $13 \mathrm{mM} \mathrm{As(III)} \mathrm{by} \mathrm{MnO}_{2}$ (solid symbols) and the resultant reductive dissolution of $\mathrm{Mn}^{2+}$ (open symbols). At 40 hours, $86 \%, 55 \%$ or $27 \%$ of $\mathrm{MnO}_{2}$ was reductively dissolved at $0.15,0.25$ or $0.5 \% \mathrm{MnO}_{2}$ doses, respectively. (b) Correlation between the amount of $\mathrm{As}(\mathrm{III})$ oxidized versus $\mathrm{Mn}^{2+}$ reductively dissolved.
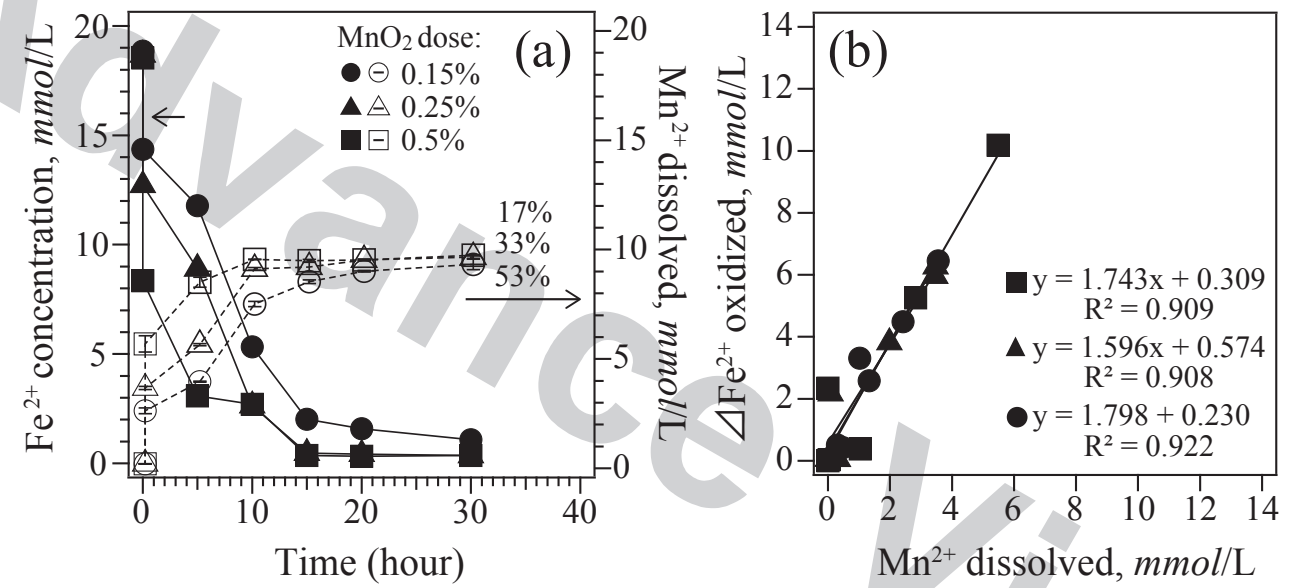

Fig. 2 The effect of $\mathrm{MnO}_{2}$ as an oxidant for $\mathrm{Fe}^{2+}$ in acidic solutions $\left(\mathrm{pH}_{\text {initial }} 1.5\right)$. Different $\mathrm{MnO}_{2}$ doses $(\mathbf{O} 0.15 \%$; $\Delta \triangle 0.25 \%$; $\square 0.5 \%$ ) were compared: (a) The oxidation trend of $18 \mathrm{mM} \mathrm{Fe}^{2+}$ by $\mathrm{MnO}_{2}$ (solid symbols) and the resultant reductive dissolution of $\mathrm{Mn}^{2+}$ (open symbols). At 30 hours, $53 \%, 33 \%$ or $17 \%$ of $\mathrm{MnO}_{2}$ was reductively dissolved at $0.15,0.25$ or $0.5 \% \mathrm{MnO}_{2}$ doses, respectively. (b) Correlation between the amount of $\mathrm{Fe}^{2+}$ oxidized versus $\mathrm{Mn}^{2+}$ reductively dissolved.

proceeds instantly upon contact with $\mathrm{MnO}_{2}$ (accounting for $23-55 \% \mathrm{Fe}^{2+}$ oxidation) in the first phase, followed by the second slower reaction phase (Fig. 2(a)). This phenomenon was also observed by $\mathrm{Wu}$ et al., ${ }^{26)}$ wherein passivation of $\mathrm{Fe}(\mathrm{III})$-hydroxides on the $\mathrm{MnO}_{2}$ surface were thought to be the cause (more likely amorphous jarosite, $\mathrm{KFe}_{3}\left(\mathrm{SO}_{4}\right)_{2}(\mathrm{OH})_{6}$, under the highly acidic condition in this study, while not evidenced by XRD). Stoichiometrically, one mole of Mn(IV) reacts with 2 moles of $\mathrm{Fe}^{2+}$ according to eq. (4). The results shown in Fig. 2(b) are consistent with this theoretical calculation.

\subsection{Simultaneous oxidation of $\mathrm{As}$ (III) and $\mathrm{Fe}^{2+}$ by} $\mathrm{MnO}_{2}$ and the subsequent scorodite precipitation

In acidic solutions containing both $\mathrm{As}(\mathrm{III})$ and $\mathrm{Fe}^{2+}$, oxidation of $\mathrm{As}(\mathrm{III})$ nearly completed by day 4 at $0.5 \%$ $\mathrm{MnO}_{2}\left(\mathrm{As}(\mathrm{III}) 0.1 \mathrm{mM}\right.$ ), and by day 8 at $0.25 \% \mathrm{MnO}_{2}$ (As(III) $0.4 \mathrm{mM}$ ) (Fig. 3(a)). $\mathrm{pH}$ remained unchanged throughout the experiment (data not shown). The oxidation of $\mathrm{Fe}^{2+}$ progressed more rapidly than As(III) and was mostly completed by day $2\left(\mathrm{Fe}^{2+}<0.6 \mathrm{mM}\right.$; Fig. 3(b)) at both
$\mathrm{MnO}_{2}$ doses. When a smaller $\mathrm{MnO}_{2}$ dose $(0.15 \%)$ was used, the oxidation of $\mathrm{As}(\mathrm{III})$ and $\mathrm{Fe}^{2+}$ nearly plateaued after day 3 at the halfway point (data not shown). The resultant production of $\mathrm{As}(\mathrm{V})$ and $\mathrm{Fe}^{3+}$ triggered the formation of $\mathrm{As}(\mathrm{V})-\mathrm{Fe}^{3+}$ precipitates: Immobilization of Fe (Fig. 3(b)) proceeded more rapidly than that of As (Fig. 3(a)), causing the transition of the molar ratio of [Fe precipitated] to [As precipitated] $\left(\mathrm{Fe}_{\mathrm{ppt}} / \mathrm{As}_{\mathrm{ppt}}\right)$ shifting from 2.2 to $1.3-1.5$ during the reaction (Fig. 3(d)). Upon the oxidation of As(III) and $\mathrm{Fe}^{2+}, \mathrm{MnO}_{2}$ was reductively dissolved to release $\mathrm{Mn}^{2+}$ ( $24 \mathrm{mM}$ or $26 \mathrm{mM}$ at $0.25 \%$ or $0.5 \% \mathrm{MnO}_{2}$, respectively; Fig. 3(c)), according to the stoichiometry based on eq. (1) and eq. (4).

The color of $\mathrm{As}(\mathrm{V})-\mathrm{Fe}^{3+}$ precipitates turned from brown to pale-green at day 4 , indicating the transition of amorphous precursors to scorodite crystals via $\mathrm{SO}_{4}{ }^{2-}$-mediated phase transformation. ${ }^{12)}$ The precipitates were identified as crystalline scorodite by XRD at both $0.25 \%$ and $0.5 \% \quad \mathrm{MnO}_{2}$ (Fig. 4(c), (d)), while the final product remained amorphous at a lower $\mathrm{MnO}_{2}$ dose of $0.15 \%$ (Fig. 4(b)). Through this 2-stage scorodite crystallization process, ${ }^{12)} 98 \%$ As was 

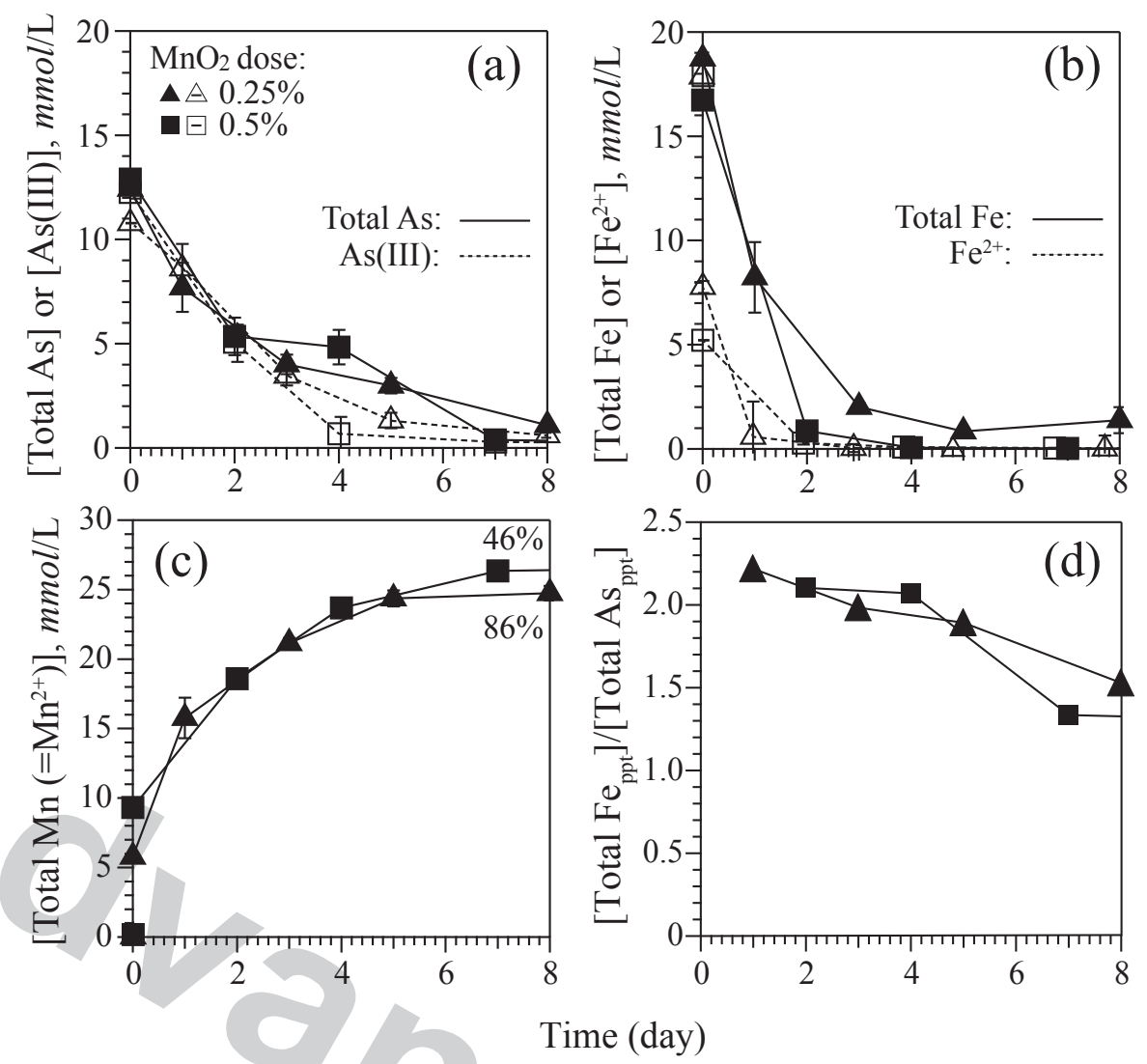

Fig. 3 Simultaneous oxidation of $\mathrm{As}(\mathrm{III})$ and $\mathrm{Fe}^{2+}$ by $\mathrm{MnO}_{2}$ and their subsequent precipitation. The effect of different initial $\mathrm{MnO}{ }_{2}$ doses ( $\triangle 0.25 \%, \square \square 0.5 \%$ ) was compared: (a) Changes in the concentration of total soluble As (solid symbols) or As(III) (open symbols). (b) Changes in the concentration of total soluble $\mathrm{Fe}$ (solid symbols) or $\mathrm{Fe}^{2+}$ (open symbols). (c) $\mathrm{Mn}^{2+}$ released into the solution via reductive dissolution of $\mathrm{MnO}_{2}$. On day $8,86 \%$ or $46 \%$ of $\mathrm{MnO}_{2}$ was reductively dissolved at 0.25 or $0.5 \%$ MnO , respectively. (d) The transition of the molar ratio of [Total Fe precipitated] to [Total As precipitated] $\left(\mathrm{Fe}_{\mathrm{ppt}} / \mathrm{As} \mathrm{spt}_{\mathrm{pt}}\right)$. The molar ratios were calculated from the concentrations of total soluble As (a) and Fe (b).
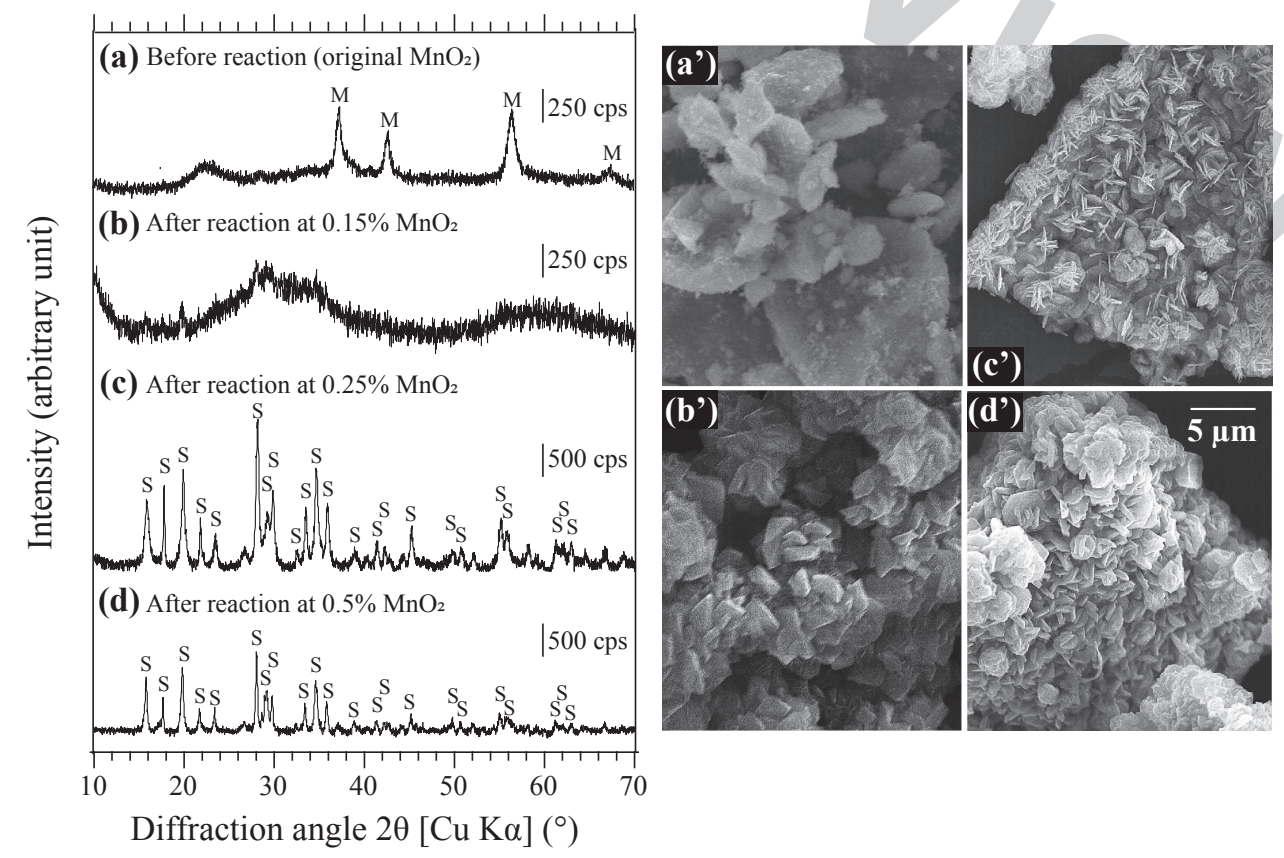

Fig. 4 XRD patterns and SEM images before $\left(a, a^{\prime}\right)$ and after $\left(b-d, b^{\prime}-d^{\prime}\right)$ the scorodite precipitation reaction at different $\mathrm{MnO}_{2}$ doses: $0.15 \%\left(\mathrm{~b}, \mathrm{~b}^{\prime}\right), 0.25 \%\left(\mathrm{c}, \mathrm{c}^{\prime}\right), 0.5 \%\left(\mathrm{~d}, \mathrm{~d}^{\prime}\right)$. XRD peaks: $\mathrm{M}\left(\varepsilon-\mathrm{MnO}_{2}\right.$; Akhtenskite, PDF No. 01-089-5171), S (scorodite; JCPDS 37-0468).

eventually immobilized using $0.5 \% \mathrm{MnO}_{2}$, and $91 \%$ As immobilized using $0.25 \% \mathrm{MnO}_{2}$ by day 8 (Fig. 3(a)). SEM images show the formation of scorodite crystals with a distinctive needle-like morphology (Fig. 4(c'), (d')), compared to the surface of original $\mathrm{MnO}_{2}$ surface (Fig. $\left.4\left(\mathrm{a}^{\prime}\right)\right)$ and amorphous precipitates (Fig. 4(b')). 
The stability of $\mathrm{As}(\mathrm{V})-\mathrm{Fe}^{3+}$ precipitates was evaluated by the TCLP test (Fig. 5). A negligible amount of Fe was leached in all tests, indicating the re-precipitation of $\mathrm{Fe}^{3+}$ at $\mathrm{pH}$ 4.9. ${ }^{8)}$ Immobilizing As as amorphous ferric arsenate (using $0.15 \% \mathrm{MnO}_{2}$ ) was shown to be unpractical due to its high leachability (As leached; $8.12 \pm 0.26 \mathrm{mg} / \mathrm{L}$ ) which is higher than the regulatory level in US and Chile $(5 \mathrm{mg} / \mathrm{L})$. The amount of As leached from crystalline scorodite was slightly different between at $0.25 \%(0.78 \pm 0.05 \mathrm{mg} / \mathrm{L})$ and $0.5 \% \mathrm{MnO}_{2}(0.11 \pm 0.01 \mathrm{mg} / \mathrm{L})$ (Fig. 5), but sufficiently low compared to most of the chemically synthesized scorodite (As leached; 0.1-13.6 mg/L). 5,6,31) Based on the amount of $\mathrm{Mn}^{2+}$ dissolved upon the oxidation of $\mathrm{As}(\mathrm{III})$ and $\mathrm{Fe}^{2+}$ (Fig. 3(c)), it can be calculated that $54 \%\left(0.5 \% \mathrm{MnO}_{2}\right)$ or $14 \%\left(0.25 \% \quad \mathrm{MnO}_{2}\right)$ of initially added $\mathrm{MnO}_{2}$ remained undissolved after the reaction, as a mixture with the $\mathrm{As}(\mathrm{V})$ $\mathrm{Fe}^{3+}$ precipitates.

\subsection{Regeneration of Mn-oxide from the post As(III) treatment water}

After the oxidative removal of $\mathrm{As}(\mathrm{III})$ as scorodite, $\mathrm{Mn}^{2+}$ ions reductively dissolved from $\mathrm{MnO}_{2}$ remained in the

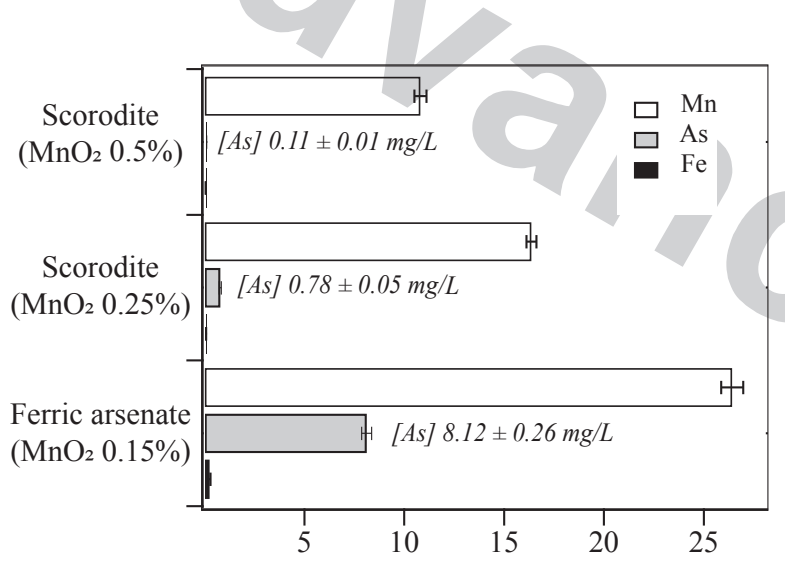

Mn, As, Fe leached after the TCLP test, $m g / \mathrm{L}$

Fig. 5 The TCLP test result (As, Fe and $\mathrm{Mn}$ ) of $\mathrm{As}(\mathrm{V})-\mathrm{Fe}^{3+}$ precipitates produced by using $0.5 \% \mathrm{MnO}_{2}$ (crystalline scorodite), $0.25 \% \mathrm{MnO}_{2}$ (crystalline scorodite) and $0.15 \% \mathrm{MnO}_{2}$ (amorphous ferric arsenate). $\mathrm{As}(\mathrm{V})-\mathrm{Fe}^{3+}$ precipitates were collected as a mixture with residual undissolved $\mathrm{MnO}_{2}$. solution. With an attempt to recover the metal value of $\mathrm{Mn}$ from the post As(III) treatment solution, the following $\mathrm{Mn}$ oxide regeneration test was conducted using the Mnoxidizing bacterium. After the scorodite precipitation reaction using $0.25 \% \mathrm{MnO}_{2}$ in Fig. 3 (day 8), the remaining solution containing $0.4 \mathrm{mM} \mathrm{As}(\mathrm{III}), 0.6 \mathrm{mM} \mathrm{As}(\mathrm{V})$ and $24 \mathrm{mM} \mathrm{Mn}^{2+}$


$0.04 \mathrm{mM} \mathrm{As}(\mathrm{V})$ and $1.5 \mathrm{mM} \mathrm{Mn}{ }^{2+}$. Regeneration of $\mathrm{Mn}$ oxide by Pseudomonas sp. SK3 cells only, sterile biogenic birnessite only, or the combination of the two is compared in Fig. 6.

The XRD peaks of Mn precipitates recovered at 140 hours (Fig. 6) were compared in Fig. 7.

Naturally occurring Mn oxides (often poorly crystalline) found in circumneutral $\mathrm{pH}$ environments are likely to be of a microbiological origin. ${ }^{32)}$ Bacterial $\mathrm{Mn}^{2+}$ oxidation is typically catalyzed by multicopper oxidase enzymes via two-step one-electron transfer reaction $\left(\mathrm{Mn}^{2+} \rightarrow \mathrm{Mn}(\mathrm{III}) \rightarrow\right.$ $\mathrm{Mn}(\mathrm{IV})){ }^{32)}$ and can be represented as eq. (5), so as the chemical $\mathrm{Mn}^{2+}$ oxidation reaction at alkaline $\mathrm{pH}$. Biogenic birnessite, formerly written as $(\mathrm{Na}, \mathrm{Ca}) 0.5\left(\mathrm{Mn}^{I V}, \mathrm{Mn}^{I I I}\right)_{2} \mathrm{O}_{4}$. $1.5 \mathrm{H}_{2} \mathrm{O}$, is known to be formed by Pseudomonas sp. SK3 in this reaction. ${ }^{33)}$

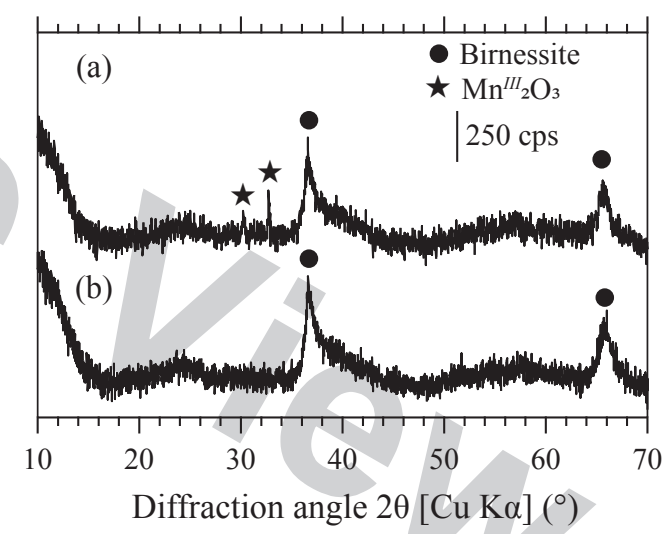

Fig. 7 XRD peaks of Mn precipitates collected at 140 hours (in Fig. 6). (a) Mn precipitates formed by birnessite seeds only. (b) Mn precipitates formed by the synergistic effect of Pseudomonas sp. SK3 cells plus birnessite seeds.
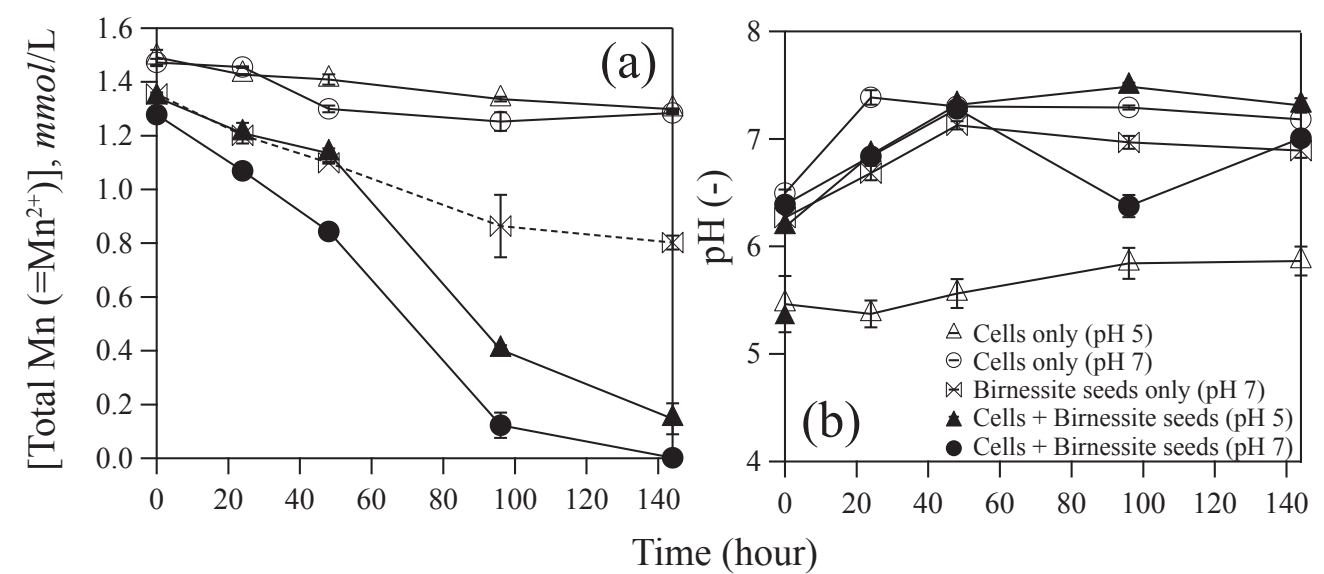

Fig. 6 Microbiological recovery of dissolved $\mathrm{Mn}^{2+}$ from the post As(III) treatment water. Changes in the total soluble Mn concentration (a) and $\mathrm{pH}$ (b) are shown. For the oxidative precipitation of $\mathrm{Mn}^{2+}$, either Pseudomonas sp. SK3 cells only $\left(\triangle \mathrm{pH}_{\text {initial }} 5.0 ; \bigcirc \mathrm{pH}\right.$ initial 7.0$)$, biogenic birnessite seeds only $\left(\triangleright \triangleleft \mathrm{pH}_{\text {initial }}\right.$ 7.0) or the combination of the two $\left(\boldsymbol{\Delta} \mathrm{pH}_{\text {initial }} 5.0\right.$; $\left.\mathrm{pH}_{\text {initial }} 7.0\right)$ were compared. 


$$
\mathrm{Mn}^{2+}+1 / 2 \mathrm{O}_{2}+\mathrm{H}_{2} \mathrm{O} \rightarrow \mathrm{Mn}^{I V} \mathrm{O}_{2}+2 \mathrm{H}^{+}
$$

As shown in Fig. 6, Pseudomonas sp. SK3 cells only were ineffective in oxidizing $1.6 \mathrm{mM} \mathrm{Mn}{ }^{2+}$, likely due to the presence of residual As in the solution. In the absence of toxic As species, Pseudomonas sp. SK3 cells were able to complete the oxidation of this amount of $\mathrm{Mn}^{2+} .33$ )

Biogenic birnessite itself could lead to autocatalytic, chemical $\mathrm{Mn}^{2+}$ oxidation by the comproportionation of $\mathrm{Mn}^{2+}$ and $\mathrm{MnO}_{2}$, especially in alkaline conditions (eq. (6)). . $^{32,34,35)}$

$$
\mathrm{Mn}^{2+}+\mathrm{Mn}^{I V} \mathrm{O}_{2}+\mathrm{H}_{2} \mathrm{O} \rightarrow \mathrm{Mn}^{I I I}{ }_{2} \mathrm{O}_{3}+2 \mathrm{H}^{+}
$$

To see the possible synergistic effect of bacterial $\mathrm{Mn}^{2+}$ oxidation (eq. (5)) and autocatalytic chemical $\mathrm{Mn}^{2+}$ oxidation (eq. (6)), biogenic birnessite only or Pseudomonas sp. SK3 plus biogenic birnessite was also tested. In addition to its effect as a chemical $\mathrm{Mn}^{2+}$-oxidizing agent (eq. (6)), birnessite can also act as the solid surface for bacterial cell attachment and seed crystals for further birnessite formation.

The use of $0.1 \%$ birnessite only was more effective than cells only but was still incapable of completing the $\mathrm{Mn}$ oxidation (43\% Mn recovery; Fig. 6): Although 0.1\% birnessite should theoretically oxidize and precipitate all $\mathrm{Mn}^{2+}$ present, secondary mineral passivation of $\mathrm{Mn}_{2}{ }_{2}{ }_{2} \mathrm{O}_{3}$ (Fig. 7(a)) on the birnessite surface significantly slowed down the reaction. The combination of the two (cells and birnessite), on the other hand, showed a synergistic effect, and the $\mathrm{Mn}^{2+}$ oxidation was promoted (Fig. 6). The birnessite particles could have provided solid support for SK3 cell attachment, enabling the cells to be less affected by the As toxicity and retain $\mathrm{Mn}^{2+}$-oxidizing activity. Fresh birnessite formed by SK3 cells could have further oxidized the remaining $\mathrm{Mn}^{2+}$, thus promoting the synergistic effect. Due to its poor crystallinity, some amorphous birnessite was dissolved when $\mathrm{pH}_{\text {initial }} 5.0$ was used, consequently pushing up the $\mathrm{pH}$ to neutral (Fig. 6(b)). At $\mathrm{pH}_{\text {initial }} 7.0$, the $\mathrm{Mn}^{2+}$ oxidation was the most effective and was completed by 140 hours.

Mn oxide regenerated from the post As(III) treatment solution was poorly crystalline birnessite and it was not feasible to reuse it as the oxidant for further scorodite production under the highly acidic $\mathrm{pH}$ (Okibe, unpublished data). However, our separate study demonstrated that such "bioactive" birnessite (birnessite minerals retaining active Mn-oxidizing bacterial cells) could be effectively utilized as the column carrier for the continuous oxidation treatment system for more dilute $\mathrm{As}(\mathrm{III})$ solutions under neutral $\mathrm{pH}^{36}$ )

Studies are ongoing further to acclimate Mn-oxidizing bacteria to As(III). Also, our separate studies indicate that optimization of chemical/microbial synergistic effect could allow higher $\mathrm{Mn}^{2+}$ load upon regeneration of $\mathrm{Mn}$-oxide (Okibe, unpublished data). This Mn recycle step could be made more robust upon such further improvement.

\section{Conclusion}

$\mathrm{As}(\mathrm{III})$ was readily oxidized to $\mathrm{As}(\mathrm{V})$ by $\mathrm{MnO}_{2}$ with a molar ratio of $\Delta[\mathrm{As}(\mathrm{III})$ oxidized $] / \Delta[\mathrm{Mn}$ dissolved $]$ at around $1 . \mathrm{Fe}^{2+}$ was oxidized to $\mathrm{Fe}^{3+}$ by $\mathrm{MnO}_{2}$ with a molar ratio of $\Delta\left[\mathrm{Fe}^{2+}\right.$ oxidized $] / \Delta[\mathrm{Mn}$ dissolved $]$ at around 2 $\left(\mathrm{pH}_{\text {initial }}\right.$ 1.5). In acidic solutions containing both ions, simultaneous oxidation of $\mathrm{As}(\mathrm{III})$ and $\mathrm{Fe}^{2+}$ was observed, and the resultant $\mathrm{As}(\mathrm{V})$ and $\mathrm{Fe}^{3+}$ triggered the formation of crystalline scorodite $\left(98 \%\right.$ As immobilized at $0.5 \% \mathrm{MnO}_{2}$ and $91 \%$ As at $0.25 \% \mathrm{MnO}_{2}$ by day 8 ). Scorodite was sufficiently stable based on the TCLP test $(0.11 \pm 0.01 \mathrm{mg} / \mathrm{L}$ at $0.5 \% \quad \mathrm{MnO}_{2}, \quad 0.78 \pm 0.05 \mathrm{mg} / \mathrm{L}$ at $\left.0.25 \% \quad \mathrm{MnO}_{2}\right)$, compared to the regulatory level in US and Chile $(5 \mathrm{mg} / \mathrm{L})$. Upon the oxidation of $\mathrm{As}(\mathrm{III})$ and $\mathrm{Fe}^{2+}, 54 \%$ (at $0.5 \% \mathrm{MnO}_{2}$ ) or $14 \%$ (at $0.25 \% \mathrm{MnO}_{2}$ ) of initially added $\mathrm{MnO}_{2}$ remained undissolved after the reaction. It was possible to recycle dissolved $\mathrm{Mn}^{2+}$ from the post $\mathrm{As}(\mathrm{III})$ treatment solution via microbiological $\mathrm{Mn}$ oxide regeneration as amorphous birnessite, which could be of use in the oxidation treatment of more dilute As(III) solutions at neutral $\mathrm{pH}$.

\section{Acknowledgment}

S.K is grateful for the financial assistance provided by the Kyushu University Advanced Graduated Program in Global Strategy for Green Asia.

\section{REFERENCES}

1) W.R. Cullen and K.J. Reimer: Chem. Rev. 89 (1989) 713-764.

2) D. Lievremont, P.N. Bertin and M.C. Lett: Biochimie 91 (2009) 12291237.

3) P.A. Riveros, J.E. Dutrizac and P. Spencer: Can. Metall. Quart. 40 (2001) 395-420.

4) A.J. Monhemius and P.M. Swash: JOM 51 (1999) 30-33.

5) S. Singhania, Q. Wang, D. Filippou and G.P. Demopoulos: Metall. Mater. Trans. B 37 (2006) 189-197.

6) T. Fujita, R. Taguchi, H. Kubo, E. Shibata and T. Nakamura: Mater. Trans. 50 (2009) 321-331.

7) A. Iizuka, K. Shinoda and E. Shibata: Mater. Trans. 59 (2018) 843-849.

8) M. Tanaka and N. Okibe: Minerals 8 (2018) 23.

9) P. Gonzalez-Contreras, J. Weijma and C.J.N. Buisman: Cryst. Growth Des. 12 (2012) 2699-2706.

10) N. Okibe, M. Koga, S. Morishita, M. Tanaka, S. Heguri, S. Asano, K. Sasaki and T. Hirajima: Hydrometallurgy 143 (2014) 34-41.

11) N. Okibe, S. Morishita, M. Tanaka, K. Sasaki, T. Hirajima, K. Hatano and A. Ohata: Hydrometallurgy 168 (2017) 121-126.

12) M. Tanaka, N. Okibe and K. Sasaki: Hydrometallurgy 180 (2018) 144152.

13) N. Okibe and Y. Fukano: Biotechnol. Lett. 41 (2019) 1403-1413.

14) N. Okibe, R. Nishi, Y. Era and T. Sugiyama: Mater. Trans. 61 (2020) 387-395.

15) J.E. Post: Proc. Natl. Acad. Sci. USA 96 (1999) 3447-3454.

16) S.E. Fendorf and R.J. Zasoski: Environ. Sci. Technol. 26 (1992) 79-85.

17) A. Manceau, V.A. Drits, E. Silvester, C. Bartoli and B. Lanson: Am. Mineral. 82 (1997) 1150-1175.

18) J.K. Yang, M.O. Barnett, J. Zhuang, S.E. Fendorf and P.M. Jardine: Environ. Sci. Technol. 39 (2005) 7102-7110.

19) M.J. Scott and J.J. Morgan: Environ. Sci. Technol. 29 (1995) 18981905.

20) J.N. Moore, J.R. Walker and T.H. Hayes: Clays Clay Miner. 38 (1990) $549-555$.

21) C. Tournassat, L. Charlet, D. Bosbach and A. Manceau: Environ. Sci. Technol. 36 (2002) 493-500.

22) D.F.A. Koch: Aust. J. Chem. 10 (1957) 150-159.

23) B.J. Lafferty, M. Ginder-Vogel and D.L. Sparks: Environ. Sci. Technol. 44 (2010) 8460-8466.

24) X. Han, Y.L. Li and J.D. Gu: Geochim. Cosmochim. Acta 75 (2011) 368-379.

25) K. Ehlert, C. Mikutta and R. Kretzschmar: Environ. Sci. Technol. 48 (2014) 11320-11329. 
26) Y. Wu, W. Li and D.L. Sparks: J. Colloid Interface Sci. 457 (2015) 319-328.

27) Y. Wu, R.K. Kukkadapu, K.J.T. Livi, W. Xu, W. Li and D.L. Sparks: ACS Earth Space Chem. 2 (2018) 256-268.

28) D.H. Caldwell and R.B. Adams: J. Am. Water Works Ass. 38 (1946) 727-730.

29) J. Murphy and J.P. Riley: Anal. Chim. Acta 27 (1962) 31-36.

30) S. Blomqvist, K. Hjellström and A. Sjösten: Int. J. Environ. Anal. Chem. 54 (1993) 31-43.

31) M.L. Caetano, V.S.T. Ciminelli, S.D.F. Rocha, M.C. Spitale and C.L.
Caldeira: Hydrometallurgy 95 (2009) 44-52.

32) B.M. Tebo: Annu. Rev. Earth Planet. Sci. 32 (2004) 287-328.

33) S. Kitjanukit, K. Takamatsu and N. Okibe: Water 11 (2019) 507.

34) J.W. Murray, J.G. Dillard, R. Giovanoli, H. Moers and W. Stumm: Geochim. Cosmochim. Acta 49 (1985) 463-470.

35) T. Takashima, K. Hashimoto and R. Nakamura: J. Am. Chem. Soc. 134 (2012) 1519-1527.

36) R. Nishi, S. Kitjanukit, K. Nonaka and N. Okibe: Hydrometallurgy 196 (2020) 105416.

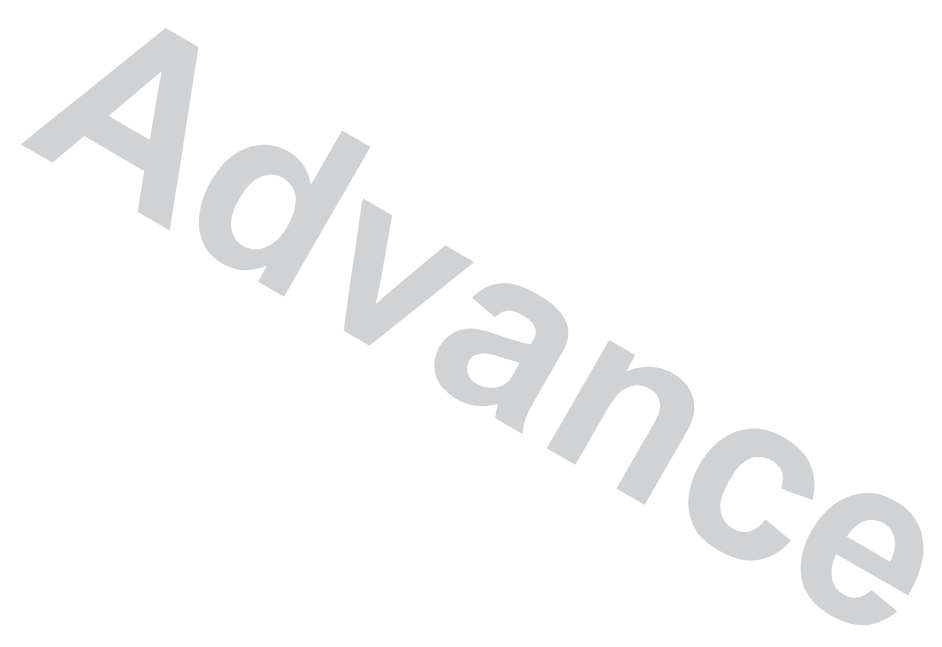

